\title{
ПОЛИМОРФНЫЕ ВАРИАНТЫ ГЕНОВ LEP, LEPR У ДЕТЕЙ С ОЖИРЕНИЕМ
}

\author{
Кочетова О.В., Шангареева 3.А., Корытина Г.Ф. \\ ИБГ УФИЦ РАН, Уфра \\ Башкирский государственный медицинский университет, Уфа
}

ЦЕЛЬ: изучить ассоциацию полиморфных локусов генов лептина (LEP rs2167270) и лептинового рецептора (LEPR rs 1137100) у детей с ожирением.

МАТЕРИАЛЫ И МЕТОДЫ: в Исследовании бЫли использованы образЦы ДНК 380 детей, проживающих в городе Уфе. Из них 170 пациентов с ожирением и избыточной массой тела и 210 детей без признаков ожирения. Средний возраст детей в группе с ожирением составил $7.1 \pm 2.3$ лет, в контрольной группе $7.3 \pm 2.5$ лет (возраст исследуемой группы варьировал от 2 до 10 лет). Антропометрическое измерение было осуществлено в соответствии со стандартными методами. Для статистического анализа избыточный вес был определен следующим образом: для детей до 5 лет (z>+2 балла) (http://who.int/childgrowth/ standards/ru/), для детей в возрасте от 5 до 10 лет (z>+1)(http://who.int/growthref/who2007_bmi_for_age/ en/index.html). Выборка сформирована на базе многопрофильного стационара (ГКБ №17 г. Уфа).

Генотипирование. ДНК выделяли из лейкоцитов периферической крови с использованием метода фенольно-хлороформной очистки. Анализ полиморфных локусов генов rs2167270 лептина (LEP) и rs1137101 лептинового рецептора (LEPR) определяли методом ПЦР-ПДРФ анализа [Крылов М. Ю., 2010]. Результаты: Показано отсутствие статистически значимых различий по распределению частот генотипов и аллелей генов LEP (rs2167270) и LEPR (rs1137100) между пациентами с ожирением и детьми контрольной группы. Анализ количественных параметров метаболических нарушений выявил ассоциацию локуса $r s 2167270$ гена $L E P$ с уровнем глюкозы-натощак ( $\mathrm{P}=0.032)$. Носители генотипа $A A$ имели высокий уровень глюкозы крови, достигавший 6.25 ммоль/л. Анализ полиморфного локуса rs 1137100 гена $L E P R$ выявил ассоциацию с весом при рождении, весом в настоящее время и показателями Z-score и уровнем перцентилей были установлены для локуса rs 1137100 гена $L E P R(\mathrm{P}=0.02, \mathrm{P}=0.032, \mathrm{P}=0.028, \mathrm{P}=0.04)$. Носители аллеля А (генотипы $A A$ и $A G)$ имели более высокую массу при рождении и в настоящее время, высокие показатели Z-score и уровня перцентилей.

ВЫВОдЫ: таким образом, в результате проведенного исследования выявлена ассоциация с антропометрическими характеристиками у детей по локусу rs 1137100 гена LEPR и установлена ассоциация локуса rs2167270 гена LEP и уровнем глюкозы. Вместе с тем статистически значимых различий в распределении анализируемых локусов в сравниваемых группах детей выявлено не было.

Работа выполнена в рамках государственного задания Минобрнауки РФ (№AAАA-А16-1 16020350031-4) и при частичной поддержке грантов РФФИ (проект №20-013-00261). 